\title{
African Socialism: A Critique
}

\author{
Alofun, Grace Olufolake O. \\ College of Social \& Management Sciences, Achievers University, Owo P.M.B 1030Owo, Ondo State, Nigeria
}

\begin{abstract}
Many African countries gained independence during the 1960s, and some of these newly formed governments rejected the ideas ofcapitalism in favour of a more Afrocentric economic model. Advocates of African socialism claimed that it was not the opposite of capitalism, nor a response to it, but something completely different. Therefore, this paper examines the context that gave birth to the concept African socialism, explicate the meaning of the concept; briefly highlight what African socialism means to some of its proponent. Also it shall elucidate some issues that have emerged in African socialism, the implication of the emergent issues for the contemporary society shall be considered, then follows a critical evaluation and conclusion.
\end{abstract}

Key Words: African, Socialism, Communal, Economic, Development

\section{Introduction}

The concept African socialism emerged in African thoughts in the 1950's at a time when many of the African countries were getting ready for independence. Then the problem confronted by the first crop of political elites or leaders in their various territories was how to mobilize the values and the energies of their people, tradition and modern, for the development of the territories after independence. It was within this atmosphere that African socialism emerged as a (compass) body of ideas. (Agbaje, 1991) Some of these African leaders and proponents of African socialism are Julius Nyerere of Tanzania, L. S. Senghor of Senegal, kwamehNkurumah of Ghana, NnamdiAzikiwe and ObafemiAwolowo of Nigeria and SekouToure of Guinea

According to Friedland and Rosberg 1964, the common principles of the various versions of African socialism were: economic development guided by a large public sector, incorporating the African identity and what it means to be African, and the avoidance of the development of social classes within society Senghor claimed that "Africa's social background of tribal community life not only makes socialism natural to Africa but excludes the validity of the theory of class struggle," thus making African socialism, in all of its variations, different from Marxism and European socialist theory

What then is African socialism? The fact that the originators and proponents are of different temperament and have not often spoken with one voice makes it difficult to give a univocal meaning of the concept. However for a working definition we may say that African socialism is an attempt to recapture and modernize the communal way of life practiced by the traditional African before the exposure to the world and values of the white man. (Agbaje, 1991) Also, we can say that it is a search for an altogether different type of asocial system with its root in African soil.

It was in this vein that Tom Mboya conceives of African socialism as a political philosophy which stands to restore national values, communal social practice and above all to restore the traditional values in the African socialist mentality and outlook, and tocreate more values in the changing world of money economy tobuild an economy which reflects the thinking ofthe great majority of people. Mboya's list of basic values and social practices of traditional African consist of the communal spirit, hospitality, hard-work,generosity, acceptance and practice of equalitarianism, communal ownership of land, equality of opportunities for all, tribal loyalty and so on.

Nyererealso views African socialism or "Ujamaa Socialism" as he terms it, asmore than a political system, it is a philosophy, a world view as well as a gateway to African selfhood. Nyerere asserts that African socialism is:

Essentially an attitude of the mind which involves a change in personal attitude and a reconciliation of individuals but goes beyond these to effect structural change consistence with the socialist outlook, creating a pattern of justicein which creative and justice in which equality and freedom of all will be assured.

Julius Nyerere is one of the most original political thinkers to emerge from Africa. He led his country Tanzania to independence through the party he founded in 1952- the Tangayika African National Union (TANU). At independence in 1961, Nyerere was elected president of Tanzania. On $7^{\text {th }}$ February, 1969, he made the famous Arusha declaration, which laid down new social ways of pursuing development in Africa. His Ujamaa philosophy emphasized breaking Tanzania into small sizeable villages and pursue intensive grass root human and material development. The concept Ujamaa comes from the Swahili for extended family or 
familyhood, which is distinquished by several key characteristics such that a person becomes a person through the people or community (Brockway, 1963; Friedland and Rosberg1964) In spite of the difficulties Nyererefaced in the pursuit of his Ujamaa, he is recognised all over the world as one of the few African leaders with integrity. His death in 1991 was mourned by many statesmen all over the world. (Osam, 2002)

Leopold S. Senghor sees African socialism as a form of socialism that is peculiarly African by saying.

Our socialism is not that of Europe. It is neither atheistic communism nor quite the democratic socialism of the second international. We have modestly called it the African mode of socialism.

Senghor believes that two elements are central to African socialisms, namely "economic democracy' and 'spiritual freedom".

Likewise,kwamehNkurumahexplains African socialism through the communal life practiced by traditional African, he says;

Anyone who seeks the socio-political ancestors of socialism, the one must go to communalism. Socialism has characteristics in common with communalism, just has capitalism is linked with feudalism and slavery.

KwamehNkurumah avers further that the traditional African as an attitude towards man which can describe as being socialistic. This he believes arises from the fact than man is regarded in Africa as primarily a spiritual being, a being endowed originally with acertain inward dignity, integrity and value, Nkurumah believes that the idea of the original value of man imposes duties of a socialist kind upon him.

Kwame Nkurumah was born inNkrofol in Ghana in 1909 he was first trained as a teacher at Achimota college. In 1935, he left Ghana (the gold coast) to study at the Lincoln University in America. He was involved in the fifth pan-AfricanCongress in Britain in 1945, at a time when he was secretary of the West African secretariat. He returned home in 1947 and became the secretary of the United Gold Coast Convention (UGCC), the major nationalist of that period. He broke away from the party in 1947 and formed the Convention People's Party(CPP), because he felt that the UGCC was becoming too conciliatory to the colonial government and therefore not vary far reaching in their demands. He became the first Prime Minister of British Gold coast in 1951 and at independence in 1957 he became the first President of Ghana. As prime minister he instituted a one party system and declared himself life president. He was actively involved in developing Black Nationalism and Pan-Africanism. Ghana became the symbol of pride for the black race the world over, but the economic and political realities of Ghana were discouraging. He was overthrown by a military coup. He died in exile in 1972 (Edim, 2002)

From the works of thedifferent proponents of African socialism emerge the following issues or element as articulated by Agbaje (1991); the nature of man,the nature and role of the family and kinship ties, the society the nature of government and the state, and the peculiar nature African socialism.

The Nature of Man; man according to the proponent of African socialism, isquite different from the individualistic picture inherent in literature from the west, for them, man is intrinsically a communal animal. He depends on and is part of the community not only for economic and social reasons alone, but also for spiritual succour. African Socialism thus focuses on the needs of man, the individual as a member of the community, a community in which he is not in conflict either with himself or others. Therefore, man is conceived by the African socialist as being in a symbiotic relationship with the community, they then believe thatthe encouragement of the past model in the present African world, will generate bonds of brotherhood, unity and conflicts free solidarity.

The Nature and Role of The Family and Kinship TiesThe proponents of African socialism view the family and kinship ties as very crucial social structures in bringing about community of relationships, which will work against the development of explicatory relationship and are therefore conducive to the building of the communocracy they envisaged. This sort of argument is pushed forward in Julius Nyerere's 'ujamaa socialism'. On Society; African socialism portrays traditional African societies as being free of conflict due to their being egalitarian. For proponents of African socialism, traditional society of the past was one in which social wealth was used for the benefit of all and there existed no oppression and no diversity of society into opposing and hostile camps. Thus in the modern day proponents tend to discourage all forms of opposition(social, economic, and political) which might generate social conflict.

On Government and The State; as earlier stated, African socialism at its inauguration was a tool for the mobilization of the resources of the new African nations for political, economic as well as social development. As a result of this, African socialists tend to see the government and the state as communocratic means of mobilizing natural resources for development. Hence, dissent is discouraged because it could distract the overriding goal of unity and purpose in the search of development African socialism therefore encourages the development of one party regime.

Peculiar Nature of African Socialism: Proponents of African socialism argue that is not a form of Marxist socialism based on the proletariats, who wield power and dictate to the bourgeois nor is it a form of Chinese collectivism, whose basic unit is the commune, established on the basis of an oath of mutual aid among the 
participants or communism based on the holding of property in common, since the state would have withered away. The form of socialism campaigned for by these first crop of African leaders is not new to African. The traditional Africa that they believe was socialist in his mental outlook, and his life was governed by indigenous socialist rules, customs and institution.

From the foregoing, African socialism as an ideological orientation presents to the modern Africa (individual and the society), messages from the past which 'it' can learn a lot from concerning the traditional past, Onuoha (1971) avers, “... it has a beauty of its own. It was highly integrated in a peculiar way and embodied those tracts by which Africans are to be distinguished as a people".

Therefore, African socialism calls the modern man back to the land and culture as the source of authentic social progress and self-hood for there seem to be regretful awareness by the present day African, that being exposed to European education, culture, values and capitalist exploitative tendency has eroded from the African his true self and has alienated him for his development, hence the need to pursue progress from the roots of the African culture.

Another suggestion is that it is possible to 'recapture the traditional values and worldviews of his race and adapt them to the modern needs for scientific progress and international co-operation'. (Oladipo, 1995)

We have to applaud the first crop of African leaders for reacting to the capitalist exploitative hegemony of the west under the influence of colonialism and its advanced stage of neo-colonialism, at a point in African history by propagating an African traditional ideological orientation; African socialism, and stating emphatically that it is peculiarly African. Their efforts not withstanding we need to critically interrogate their assumption about the past and its suggestion for the present, especially those connected with the society and the individual. Firstly the socialist present the African past society as one that is conflict free but from history we know that this was not the case, there were cases of intra/inter-tribal wars. For example, theEgbas of Ogun state were formerly part of the old Oyo Empire, but incessant conflict led to their migration to their present domain. Also, there were criminals and exploiters in the traditional societies of Africa, as we have in the present capitalist states.

Secondly, communal co-existence suggested by African socialism for the present African socialism is not plausible in an over populated geographical area as the African states, except if sanctions will be applied in proportions to the populations. However, that could be a drift towards capitalism. Communalism is not peculiar to Africa, it is found in traditional industrial societies all over the world.

Thirdly, African socialists assert that the bond of brotherhood and unity, in the traditional society of Africa was very strong; they therefore suggest that these brotherhood and unity should be encouraged in the modern society. This is really a good suggestion; but then if the bond of brotherhood and unity was that strong, why did Africans sell their fellow African brothers into slavery in exchange for the goods of the white man?

Again, it is believed that the values extolled as African values, values such as communal spirit, hospitality, hardwork, generosity, and altruism are not peculiar to Africa, these values are human values, encouraged by human beings all over the universe, since human nature is universal.

Finally, as a results of the above short comings and the fact that African socialist have not been able to translate their theory into practise in the present African states. In this present dispensation many Africans are living below the poverty line, many of our roads are bedevilled with 'pot-wells' not 'holes', we witness epilepsy in our power supply, unavailability of portable water, unemployment, underdevelopment, security threat and a lot more challenges. (Ayittey, 1990) Therefore, African Socialism has fatally failed as a socio-economic blueprint for African countries. Then one is tempted to say that African socialism is nothing but a myth. A story told to explain the nature of man and the society in ancient Africa. Hence the need to look for another blue-print for the development of Africa and 'deliverance' from the present quagmire

Therefore, we suggest that instead of going back to the ancient past and emphasising the superiority of the lifestyle over the contemporary lifestyle, we should encourage the human values that will make African society the "best possible world" for the actualisation of the potentials of the individual.

\section{References}

[1]. Agbaye, A (1991)AfricanPolitical Thought Ibadan: Department of Adult Education U.I., UP

[2]. Ayittey, G. B. The End of African Socialism, The Heritage Foundation. Retrieved from www.heritage,org on $9^{\text {th }}$ May, 2014

[3]. Brockway, F. (1963) African Socialism. London: The Bodley Head

[4]. Friedland, W. H. and RosbergJr, C. G. (1964) African Socialism. California: Stanford University Press

[5]. Mboya, T.(1963) Freedom and African London: Andrew Deutoch,

[6]. Nkrumah, J. K. (1975) "Conscientism" in G.M Mutsoamd S.W Rohio, Readings in African Political Thoughts London: Heineman,

[7]. Nyerere, J. K. (1975) "Ujamaa-The basis of African socialism" in (ed) G.M. Mutisco and S.W. RohioReadings in Africa Political Thought London: Heineman, 1975

[8]. Oladipo, O. (1995) "Reason, Identity and the African Quest: The Problem of Self-definition in African Philosophy" in African Today, vol.42, No. 3

[9]. Onuoha, B. (1971) Elements of African Socialism New York: Friendship Press

[10]. Edim, O. O. (2002)Essay on Socio-Political Philosophy Unical. Unpublished Work

[11]. Senghor, L. S.(1998) "Negritude and African Socialism" in (ED). P.H. Coetze and A.P.J. Roux, The African philosophy Reader London: Routledge 